\title{
South-South Cooperation in Africa: Historical, Geopolitical and Political Economy Dimensions of International Development
}

\author{
Kojo Sebastian Amanor
}

\begin{abstract}
This article examines how neoliberal reforms mediate and influence relationships between emergent powers and African nations centred on agricultural development. It investigates the impact of South-South relations on the nature of development and technical cooperation, aid and investment, and on the configuration of relations between states, farmers and the private sector. It examines the extent to which the experiences of China and Brazil in developing their agriculture result in qualitatively new paradigms for agricultural development, and whether they create new openings for a redefinition of development policy and practice. Moreover, the article assesses whether South-South development cooperation merely reinforces the drive to capital accumulation unleashed by global economic liberalisation, reflecting strategies by emergent powers to acquire new markets for agricultural technology, inputs, services and new sources of raw materials. In conclusion, the article questions the extent to which alternative paradigms for development cooperation can be created within the institutional framework created by neoliberal reform.
\end{abstract}

\section{Introduction}

In recent years, South-South development cooperation has come to the fore. This coincides with the global economic recession and the growing focus on Africa as a favourable source of raw materials, but also as a new frontier for financial investments and investments in largescale agriculture. There is a sharp divide in perceptions of the expansion of investment in Africa by emergent powers. Detractors argue that emergent nations are pursuing a strategy of placing commercial interests above policy reform and good governance in a framework of market liberalisation. This is countered by arguments that the investments of BRICS countries (Brazil, Russia, India, China and South Africa) create new diversified opportunities based on symmetric relations or 'soft power' rather than coercion rooted in the vestiges of colonial rule.

Like African nations, the emerging powers have also gone through processes of economic reform rooted in market liberalism during the 1980s and 1990s that have permeated and transformed their economies. This article examines how such neoliberal reforms mediate and influence the relationships between emergent powers and African nations. It investigates the impact of South-South relations on the nature of development and technical cooperation, aid, and investment, and on the configuration of relations between states, farmers and the private sector. It then examines the extent to which the experiences of China and Brazil in developing their agriculture result in qualitatively new paradigms for agricultural development, and whether they create new openings for a redefinition of development policy and practice. Moreover, the article assesses whether South-South development cooperation merely reinforces the drive to capital accumulation unleashed by global economic liberalisation, and so reflects strategies by emergent powers to acquire new markets for agricultural technology, inputs, services and new sources of raw materials. In conclusion, the article questions the extent to which alternative paradigms can be created within the institutional framework created by neoliberal reform. 


\section{Nurturing a dominant paradigm: the role of the USA}

Advocates of South-South cooperation tend to present it as distinct from previous development paradigms, suggesting that it carries no baggage from a colonial past and involves nations which have collectively experienced and struggled against colonial domination. However, the dominant paradigms of agricultural development in Africa are not just based on the heritage of colonialism. A major, perhaps underestimated, influence lies in initiatives led by the USA in the late 1940 s and 1950 s to create new paradigms for development outside of colonial structures and within the constructs of free markets. The framework for this was Point Four of the Truman declaration, the inaugural speech given by President Truman on 20 January 1949. In this address, Point Three was an overt military strategy, a call for a collective defence arrangement to counter the rise of communism, which gave birth to the North Atlantic Treaty Organization (NATO). Point Four, on the other hand, was based on an effort to spread American influence through the transfer of technology and Western democratic ideals:

More than half the people of the world are living in conditions approaching misery. Their poverty is a handicap and a threat both to them and to more prosperous areas... The United States is preeminent among the nations in the development of industrial and scientific techniques... I believe that we should make available to peace-loving peoples the benefits of our store of technical knowledge in order to help them realize their aspirations for a better life. And in cooperation with the other nations, we shall foster capital investment in areas needing development... The old imperialism - exploitation for foreign profit has no place in our plans. What we envisage is a program of democratic fair dealing... Greater production is the key to prosperity and peace. And the key to greater production is a wider and more vigorous application of modern scientific and technical knowledge. (Truman 1949)

During the 1950s and early 1960s, the USA built a programme of technical cooperation, which was delivered through the International Development Advisory Board (which later evolved into the United States Agency for
International Development (USAID)) and through the Rockefeller and Ford Foundations (Perkins 1997; Arnove 1982). These three organisations were highly instrumental in organising an international institutional framework for agricultural research to contain the three perceived threats of famine, overpopulation and communism. The work of these three agencies resulted in the building of new scientific and technical institutions within African countries, the education of an epistemic community of African scientists and technicians ingrained with Western liberal values, and the creation of new international agricultural research structures that expanded plant breeding and agricultural technology innovations developed within the USA for wider application throughout the developing world. This formed the institutional infrastructure for the creation of the CGIAR (Consultative Group for International Agricultural Research) system and the architecture through which the Green Revolution was initiated.

Within African countries, new technical and research institutions were funded and international agricultural research facilities such as IITA (the International Institute for Tropical Agriculture, established with headquarters in Nigeria as part of the GGIAR) were created to support adaptive research within national institutions and create new directions for agricultural research. Through these initiatives new technical and research institutions came into being and were shaped on the basis of US institutions and institutional values.

Under colonial rule, the creation of an African scientific and technical cadre had been given low priority. Indeed, it was not until the 1950s that the colonial authorities began to build a network of national agricultural research and experimentation stations and hire expatriate scientific and technical staff (Hodge 2007). As a consequence, African nations attained national sovereignty with a very rudimentary agricultural research infrastructure that was seriously understaffed.

The building of technical capacity involved overseas training programmes. The USA provided programmes and scholarships for Africans to gain technical, scientific and social science education within US institutions. Through these training 
programmes the USA was able to build influence within the evolving development institutions within developing countries. Assessing these developments, Papanek (1969: 183) comments:

As a result of progress towards a professional consensus, foreign economists working in many less developed countries have immediate and national allies in their national colleagues, who share their professional language and often their goals. The differences between foreign and national economists are disappearing. The universities' future training, research and institutional involvement in the less developed world needs to take this development into account.

Gouldner (1982) argues that the overseas training programmes co-opted leaders of developing countries into an 'international occupation of experts and technicians who constitute a specific status group with status interests they wish to protect and advance' (Gouldner quoted in Arnove 1982: 318). These programmes were initiated alongside programmes of learning about doing development, which also drew the social sciences into international development, including rural sociology, and anthropology.

This led to the development of African Studies and Development Studies departments in American universities. More practical learningby-doing programmes also involved the Peace Corps Volunteers. In addition, open learning was complemented with covert learning, with US university researchers in Africa and Peace Corps volunteers providing lucrative potential for espionage in the context of the Cold War (Stockwell 1984).

The US foundations supported the creation of networks to build the leadership capacities of African researchers and experts to recognise, understand and solve development problems. They fostered linkages between an intelligentsia across national borders within Africa with intellectuals within the USA. They created a series of mutually supporting linkages among national organisations to meet national development objectives. The US foundations tended to define and shape the research and development objectives of these networks to foster US interests rather than utilise them to open up new areas of research and understanding outside of US concerns. Nevertheless the foundations' support for research was often subtle, sometimes initiating research in areas critical of US interests. For instance, much of the research on what became dependency theory in Latin America was funded by the Ford Foundation. The independence of the foundations from the US government enabled them to initiate research in areas wary of US geopolitical ambitions and bring them into US circles of debate, by appeal to a nebulous concept of global development free of political interest (Arnove 1982).

During the 1950s and 1960s, much of the rhetoric of US commitment to international development in Africa took place in the context of opening up Africa to free markets and new influences; strategies that are now referred to as 'soft power'. Unlike in South America, there was no previous history of US colonialism or imperial control, with the exception of Liberia. However, this was marred by the rapid escalation of the Cold War, which led US geopolitical interference to gain spheres of influence, to the Korean War, the Vietnamese War, and support for coups d'état throughout the world that toppled leaders who opposed US interests.

US development programmes were initiated in the context of the Cold War. Soviet support for the anti-colonial struggle had won it many friends within Africa. This led to a divide in the bid to build African unity in the 1960s between the Casablanca Group made up of Ghana, Guinea, Mali, Egypt, Algeria and Morocco, committed to radical socialist programmes and linkages with the Soviet Union, and the Monrovia group of more conservative states wishing to remain within the ambit of the colonial powers and US influence. Emperor Haile Selassie eventually negotiated a compromise between the two networks, resulting in the setting up of the Organization of African Unity (OAU) headquarters in Addis Ababa.

\section{Competing interests}

As a result of these competing geopolitical interests, international development has never been hegemonic, but always a contested site of conflicts over knowledge and politics. While the USA was able to shape the overriding architecture of international development, many 
African countries had technical cadres trained in the Soviet Union, eastern Europe and China, and implemented mixed development plans combining elements of state planning, cooperatives and state farms, with US models of rural development, community development and the land grant system of agricultural extension.

Many of the more radical African governments attempted to steer a more autonomous course, becoming members of the Non-Aligned Movement, which itself originally arose as an initiative of Yugoslavia, following its disagreements with the Soviet Union. The main advocates of the Non-Aligned Movement in the early 1960s included presidents Tito of Yugoslavia, Nasser of Egypt, Nkrumah of Ghana, Sukarno of Indonesia, and Nehru, the prime minister of India. The main principles included respect for territorial integrity and sovereignty, mutual non-aggression, non-interference in the domestic affairs of other states, relations based on equality and mutual benefit, and peaceful coexistence. Many of the principles were initially developed in the context of early diplomatic relations between China and India, and China has continued to build upon these principles in its dealing with developing countries. Many of these values are therefore echoed in the articulation of principles for South-South relations in current discourse.

During the 1970s, many African governments became disillusioned with international development and sought alternative visions (Arrighi 2002). During this era dependency theory was in vogue. The Non-Aligned Movement was instrumental in launching the Declaration for the Establishment of a New International Economic Order (NIEO), which was adopted by the UN General Assembly in 1974. The NIEO was a forum for promoting dialogue on restructuring unequal trade relations between developed and developing countries. However, with the collapse of the Soviet Bloc and the end of the Cold War, combined with the hegemony of the USA in international relations, the influence of the Non-Aligned Movement and the NIEO has declined. Nevertheless, these principles continue to influence the rhetoric of South-South cooperation, although it occurs in contexts that are quite different from the original conception of North-South unequal relations and Southern solidarity based on self-sufficiency.
Ultimately, the world economic recession of the 1970s resulted in the collapse of the Soviet Bloc and the bankruptcy of many African nations which were forced to apply to the IMF for support. With the decline of a bipolar world competing for spheres of influence, African states were forced to implement a set of conditionalities made up of austerity macro-policy measures and neoliberal reforms that opened up the economies to global market forces, and 'good governance' institutional reforms.

This period had a major impact on African agriculture and continues to influence the trajectories of development efforts. Within Western international development circles, the crises being faced by African governments were constructed as the result of internal constraints bad policies that undermined agricultural production. According to Bates (1981), African governments used the powerful instruments of state control and trade monopsonies to benefit a narrow circle of urban elites and party functionaries at the expense of farmers. The neoliberal 'solution' was to dismantle state control over the agricultural sector and enable farmers to take advantage of market opportunities. This thesis was elaborated by the World Bank into a theory of 'good governance' (World Bank 1989). In spite of the implementation of reform processes, African economies continued to lag behind during the 1980s and 1990s as an increasing differentiation began to appear within the former colonies, with rapid rates of growth in some Southeast Asian economies, while the GNP of African states declined an average of 5 per cent between 1960 and 1975 and 47 per cent between 1960 and 1999 (Arrighi 2002).

\section{Economic crises, reform agendas and the struggle over resources}

Arrighi (2002) argues that the world economic crisis of the 1970s resulted in a crisis of profitability that intensified global competition. The USA responded to this crisis by competing aggressively for capital worldwide to finance a growing trade and current account deficit on its own balance of payments, which resulted in an increase in interest rates everywhere and major reversals in the direction of global capital flows. In the period 1965-9, the US balance of payments recorded a surplus of US $\$ 12$ billion. By 1975-9 this had turned into a deficit of 
US $\$ 7.4$ billion and escalated to US $\$ 912.4$ billion in 1995-9 (Arrighi 2002, based on IMF figures). By 2005 the USA was running a deficit of US $\$ 700$ billion, but receiving credits of US $\$ 900$ billion as foreigners bought up government bonds and mortgage bonds (Roberts 2009). This enabled the USA to create an expanding demand for imports controlled by US manufacturers of products they no longer found profitable to manufacture in the USA, but which could be commissioned or produced by US companies by relocating manufacturing plants elsewhere. Harvey (2005: 93) suggests that:

The real secret of the US success, however, was that it was now able to pump high rates of return into the country from its financial and corporate operations (both direct and portfolio investments) in the rest of the world. It was now the flow of tribute from the rest of the world that founded much of the affluence achieved by the US in the 1990s.

Arrighi (2002) argues that these developments resulted in the rising expansion of wealth in the USA and the bifurcation of fortunes within the developing world. On the one hand, countries with large pools of cheap labour and dynamic entrepreneurial networks (largely in Southeast Asia) were able to take advantage of these developments to participate in manufacturing for export markets. On the other hand, those that had largely depended upon export of natural resources and state organisation of manufacturing sector enterprises suffered from the downturn in primary commodity prices during the 1980s, lack of capital markets and high costs of borrowing, and their lack of large supplies of industrial labour. As a consequence, while east Asian nations were able to mobilise labour supply for capital accumulation within manufacturing, the economies of sub-Saharan Africa sharply contracted and were forced to accept structural adjustment programmes.

Adherence to structural adjustment programmes was not associated with an improvement but with a further deterioration in the economic performance of African states during the 1990s (Arrighi 2002). It was not until the 2000s that growth rates began to improve in sub-Saharan Africa to an average of 5 per cent, in the context of the rise in commodity prices as a result of increasing world demand fuelled by the industrialisation of newly emergent nations. The economic recession in Europe and North America, linked to a financial and mortgaging crisis, and a crisis of profitability and faltering economic growth has resulted in new financial investments in Africa, particularly in the petroleum, mining, natural resource and agricultural sectors. Africa is now perceived to be a continent favourable to investment with returns on investment higher than in any other developing region, and a rapid growth of middleclass consumers and discretionary income (McKinsey Global Institute 2010).

Following the 2006-08 world food crisis there has been increasing interest in investment in agriculture in Africa and in the development of agriculture. This includes staple food production for the domestic market and for exports, and debates about the relative merits of supporting large-scale or small-scale agriculture linked into agri-business food chains through contractual relations. Prior to this, there had been some development in new horticultural exports in Africa complementing traditional export commodities, within a food value chain governance system determined by supermarket chains, brand manufacturers, and governments, based on notions of certification (such as EuroGap and Global Gap), standards, quality control and systems of tracking produce to their original points of production. US and European investments in the agricultural sector during the 1990s and 2000s had often been less than enthusiastic, demanding institutional and governance reform, land tenure reform, privatisation and government investment in infrastructure as a precondition to investment. For instance, the Millennium Challenge Corporation (MCG) requires governments to meet 17 different 'independent' and 'transparent' policy requirements to be eligible for support. US investors have often chosen to invest in regions other than Africa, and promising innovations in agricultural production have often suffered from intensified competition from other regions. Nevertheless, recent initiatives such as the creation of an Alliance for Green Revolution in Africa (AGRA) under the auspices of the Gates Foundation, the support of the MCG for agricultural development, and the Millennium Villages Project reflect a renewed interest in agriculture and agricultural commercialisation within Africa. 


\section{The rising powers in Africa}

In recent years new investors have rapidly moved into the African market, including China and Brazil. Between 2000 and 2008 China's trade with Africa grew by 33.5 per cent and in 2009 China overtook the USA as Africa's largest trading partner with the value of trade reaching over US\$160 billion in 2011 (Africa Research Institute 2012). Although much smaller, Brazilian trade with Africa has also grown by 400 per cent between 2002 and 2010, when it reached US $\$ 20.6$ million.

\subsection{China in Africa}

The rapid expansion of the Chinese economy and manufacturing has led to an increasing dependence of China on exports and on the US market. Exports of goods and services in China account for over 40 per cent of GDP, and a large percentage of these are destined for the US market. However, the economic downturn in the USA and the possibility of a trade war between the USA and China, as the USA aggressively seeks to regenerate its manufacturing base, has created much consternation in China about its dependence on US markets. This has led to attempts to diversify Chinese trade and stimulate domestic demands. The rapid expansion of the Chinese economy has created demands for raw materials, energy, and food. China has increasingly looked for new markets in Africa to meet these demands. This has led to a rapid expansion of trade and investment with African countries, in which China is rapidly emerging as a dominant trading partner in Africa. Chinese interests in Africa are reflected in intergovernmental cooperation, governmentsponsored projects, investments by state-owned enterprises (SOEs) and private enterprises, the large volume of trade manufacturers carried by both African and Chinese traders, and the movement of Chinese labour and small-scale investors and traders into Africa.

Although much of the growth in China has been stimulated by neoliberal reforms and the opening of new markets, this has been implemented outside of the tenets of neoliberalism and governance reforms. Moreover, many of the reforms that have been foisted onto Southeast Asian nations by the US and international multilateral organisations, in the wake of the Asian crisis, have been problematic. Those nations that have fared best have been those that have resisted further opening of their economies and retrenchment of the state (Harvey 2005; Stiglitz 2002; Bullard and Bello 1998). Within Southeast Asia, the Chinese government has been instrumental in fostering a critical multilateral appraisal of neoliberal reforms and promoting South-South dialogue (Wu and Lansdowne 2008).

This notion of South-South cooperation has also been extended into diplomatic, technical and development cooperation relations with African nations. China has sought to develop the Forum on China-Africa Cooperation (FOCAC), an intergovernmental forum through which various high-level Chinese and African leaders meet to define the parameters and scope of Chinese and African developmental ties (Buckley, this IDS Bulletin). The China-Africa Development Fund (CADFund) has opened four regional offices on the African continent and provides funding for projects within Africa and a bridge to encourage and facilitate investments of Chinese companies within Africa. The main areas of technical cooperation and investment are concerned with infrastructure development, communications, construction, dam and energy production, natural resource sectors, petroleum, mining and agriculture. China has established over 40 agricultural demonstration centres in African countries. It provides agricultural assistance that combines infrastructural development, such as in dam construction with technical training, input provisioning and storage facilities, and facilitating linkages between agricultural ministries and communities. With funding of US $\$ 1$ billion in its first phase and US $\$ 2$ billion in its second phase, the CADFund has made significant contributions to foreign direct investment (FDI) in Africa.

\section{Although China's presence in Africa has} expanded in recent years, China has a long history of development cooperation within Africa from the 1960s. During the 1980s Chinese development assistance to Africa increased with numerous development projects in many countries. The Chinese economy has considerably expanded and transformed in recent years, and the level and nature of Chinese investments in Africa have rapidly expanded. However, China's recent expansion in Africa has been preceded by a long history and experience of diplomatic and technical cooperation linkages, and participation in several multilateral forums (Guttal 2008). 


\subsection{Brazil in Africa}

In contrast with China, Brazil is a relatively new player in Africa. Its policy of promoting

South-South cooperation grows out of its regional policy in South America. Its movement into development in Africa is very recent, originating from the mid-2000s, with the visit of President Lula to 26 African countries in the early 2000s, the expansion of embassies with African countries, the organisation of the Brazil-Africa Forum, and the setting up of technical cooperation programmes, credits, and joint Chambers of Commerce for African countries (Cabral et al., this IDS Bulletin; Pierri, this IDS Bulletin; Patriota and Pierri 2013). As with China, Brazil has been suspicious of multilateral and US neoliberal reform prescriptions in the wake of the Mexican and Argentinean crises, and has propounded a development framework built on South-South cooperation.

This is reflected in a diverse portfolio of export partners in which 55 per cent of the value of exports are with Latin America, 15 per cent North America, 6 per cent Central America, 8 per cent Europe, 7 per cent Asia and 5 per cent with Africa (Aulakh 2006: 100). In contrast with China, Brazil has oriented its exports much more toward South American markets rather than the USA. Within South America, Brazil has been instrumental in opposing attempts to set up the Free Trade Area of the Americas, without the conditional elimination of US agricultural subsidies, measures to ensure access to US markets, and changes to US policy on patents. Brazil has actively supported the development of Mercorsur, a common market or free trade zone whose full members include Brazil, Argentina, Paraguay, Uruguay and Venezuela, and has become a strong advocate of South-South cooperation as a central tenet of its development policy based on economic cooperation between South American and African nations.

This notion is based on establishing joint economic investments to promote technical cooperation. Like Chinese notions of South-South cooperation, this is based on noninterference, no preconditions attached to aid, and symmetric relations in which technical cooperation develops out of expressed mutual interests. The Brazilian framework of South-South cooperation in Africa stresses the similarities of the Brazilian and African environments, the recent technical and research successes that Brazil has achieved in this environment, and the transferability of these technologies to Africa (Cabral and Shankland 2013; World Bank and IPEA 2011).

Brazilian South-South cooperation also stresses its commitment to social inclusion and the eradication of poverty and the successes that it has achieved in implementing its Bolsa Família (family allowance) programme, which targets the poor for family assistance and provides conditional financial support and school feeding programmes to ensure that the children of the poor attend school (Patriota and Pierri 2013; Pierri, this IDS Bulletin; World Bank and IPEA 2011; McCann 2008). In 2005, the Brazilian government through its Ministry of Social Development (MDS) began disseminating the precepts of the Bolsa Família or Conditional Cash Transfer (CCT) programme, as it came to be known internationally, to South Africa, Nigeria and the UK Department for International Development (DFID). In 2006, delegates from Ghana, Guinea Bissau, Mozambique, Nigeria, South Africa and Zambia made a study tour to Brazil. In 2007, the Ghanaian government implemented a version of the Bolsa Família known as the Livelihood Empowerment Against Poverty (LEAP) programme, and Benin is currently implementing a version (Stolte 2012). In 2008, the MDS, in collaboration with DFID and the International Poverty Centre for Inclusive Growth (IPG-IG), launched the Africa-Brazil Cooperation Programme on Social Development, based on technical cooperation, study tours, and distance learning. The Bolsa Família has grown into a trilateral programme, with both DFID and the World Bank supporting its dissemination in Africa (World Bank and IPEA 2011; Lindert 2006).

The Brazilian government has also signed a cooperation agreement with the Food and Agriculture Organization (FAO) to extend its Zero Hunger programme to Africa. This works through expanding public procurement of food produced by smallholders for school feeding programmes and by supporting family farm production through the More Food programme. The More Food programme in Brazil seeks to raise the productivity of Brazil's smallholder family farms by providing them with credit under preferential terms to acquire subsidised farm equipment and machinery and technical 
assistance. This has resulted in a dramatic increase in productivity of 89 per cent by area, and of income by 30 per cent. It also creates new markets for Brazilian agricultural technology in which 60 per cent of Brazil's tractor sales and 41 per cent of its agricultural machinery workforce derived from the More Food programme (Patriota and Pierri 2013; Cabral et al., this IDS Bulletin). Five African countries have currently signed agreements for the extension of this programme into their rural settings Ghana, Zimbabwe, Senegal, Kenya and Mozambique. The expansion of this programme into Africa seeks to enhance rural food security, increase productivity, address technology capacity issues, and create an expanded market for Brazilian technology. However, whether the Africa More Food programme will create technologies for small and medium farmers or lead to the provision of subsidised technologies for rich farmers remains to be seen in the implementation of the programme. Within the African agrarian economy, smallholders cultivate much smaller areas than would make tractor ownership economically viable.

South-South cooperation has formed a major framework in which Brazil has rapidly expanded its investments in Africa during the 2000s, in construction, energy, public health, agriculture, and social protection. In building South-South cooperation in Africa, Brazil tends to stress its cultural similarities with Africa, the existence of a large African diaspora in Brazil, the existence of communities within West Africa that repatriated from Brazil in the nineteenth century, and the similarity of the African physical environment with that of Brazil. However, cultural ties remain poorly developed and superficial, with few student and tourist cultural exchanges taking place, nor joint social studies research programmes being undertaken. Outside of the former Portuguese colonies there are also language barriers to communication.

Brazil has pursued a policy of opening up the economy to international market forces and investments and privatising SOEs following the 1982 Latin American debt crisis. However, state regulations and support for local capital has enabled the rapid emergence of Brazilian multinational companies, particularly dealing with natural resources, energy, construction and agri-business. Many of these companies have expanded into regional South American markets and are now moving into Africa (Schneider 2009).

Agriculture accounts for three quarters of commodity exports, the major products including soy, sugar and ethanol, chicken, beef, coffee tobacco, and orange juice. Brazil is the fourth largest agricultural exporter in the world, and many of its agri-business firms are now establishing plants in foreign countries. The largest agri-business companies are in meat processing. The three major meat processors and exporters are JBS - which became the largest beef processor in the world in 2007 following a number of aggressive takeovers, and had revenues of over US $\$ 7$ billion in that year - and Sadia and Perdigão, which in 2008 both had revenues of nearly US $\$ 5$ billion. Sadia also specialises in processed and frozen foods and Perdigão in dairy products (Schneider 2009). Ethanol is a major product, originating in attempts to create energy self-sufficiency during the period of import substitution. In contrast with China, Brazilian companies tend to depend upon employing local staff rather than Brazilians, and Brazilian economic interests are marked less by movements of Brazilians into Africa. Brazilian companies in Africa tend to be a select few large private sector companies rather than the mix of SOEs and mixed scale of private companies that characterise Chinese investments in Africa. However, communications between Brazil and sub-Saharan Africa remain poor with no direct flights, except to South Africa.

\section{Conclusion}

Although South-South cooperation appears to be a recent concept in international development cooperation, it is the culmination of longer historical processes, and is rooted in a particular historical political economy. It reflects a particular trajectory of development in which import substitution industrialisation was replaced by export-oriented growth, but one in which the successful rising powers have been able to protect and nurture their own industries and make them competitive within a global economy. While the emerging powers have introduced forms of economic restructuring that have been shaped by the global economy and market liberalism, the state has played a major role in protecting and nurturing the growth of national capital and in creating an enabling environment for the growth of both national 
capital and international investments by national industries. This has facilitated the emergence of increasing economic efficiency and companies that can compete successfully within a global economy.

Although these economic reforms have resulted in the adoption of market liberalisation, this has also been combined with a resistance to and critique of some of the policies advocated by the US and multilateral organisations, which has been carried by China into Asian regional forums and by Brazil into South American regional forums. South-South cooperation in Africa reflects a further extension of this critique into increasing competition for resources and markets with Western transnational companies (Amanor, this IDS Bulletin). South-South cooperation critiques the conditionalities that Western nations have attempted to impose on Africa, Southeast Asia and South America, and develops an alternative framework of technical assistance based on non-intervention, respect for national sovereignty and national interests. Western conditionalities are seen by both the Chinese and Brazilian governments and policymakers as imposing policies on Africa that do not necessarily meet African needs, which need to be defined by African governments and their people. The framework of South-South cooperation draws upon earlier frameworks of a new international economic order and non-alignment, although these are now framed within the concept of a market-driven economy. South-South cooperation now reflects an economic order based on private and public sector partnerships that responds to the market and is willing to make large investments within African countries, and make provisions for infrastructural development to facilitate the emergence of a modern economy. It extends the competition between US multinational companies and the new multinational agribusiness companies that have emerged in East Asia and Brazil onto the African continent. While US companies neglected Africa to invest in these new emergent economies, which were considered to have more potential, the companies that have emerged in these areas now see Africa as the new frontier for investment. This opens up African economies to rapid investment, and transforms Africa from a marginalised entity of exception into a frontier for future industrial and agriindustrial potential.
In contrast with Western donors, these new interventions set up a synergy between infrastructure development, technical cooperation and capital accumulation, which creates new demands and markets. They do not make capital investment conditional upon the creation of an enabling environment. Rather than focusing on institutional reform as a precondition for investment, they set up a process of transformation and capital accumulation that generates the material conditions for institutional change. South-South cooperation sets up a framework of diplomatic ties to facilitate trade, based on notions of symmetric exchange (soft power), and the building of intergovernmental fora to facilitate investments and business exchange. It facilitates change pragmatically based on existing economic opportunities and interests in investment and accumulation. It does not attempt to pre-define and manage change by moralising about the nature of change.

Yet in many respects these new developments have only been made possible by earlier interventions by Western powers, and must be seen in this historical context. These include the neoliberal economic conditionalities that opened up African economies to external investment, and the institutional and governance reforms that came with them. In the agricultural context, the earlier investments in training and professional development - consolidated within the UN and CGIAR systems - have also substantially contributed towards the development of science, technology and investment within the rising powers. It is very often these same people who are part of new South-South engagements in Africa. Although this long-running development support by Western states in some senses competes with Western capital, these new networks also embody alliances with fractions of Northern capital, helping to open up new markets within Africa and international markets for African products within new alliances, now framed by South-South or triangular cooperation (Amanor, this IDS Bulletin).

Thus, while frequently framed as new, different and path-breaking, we must always recognise how South-South cooperation builds upon preexisting forms of international development, neoliberal policy frameworks and the expansion 
of capital in Africa. It of course adds new perspectives, actors and networks, including important notions of social inclusion based on a mixture of market and state interventions. Yet, given the weight of historical conditioning factors and the context set by market-based reforms, both in Africa but also in the emerging powers, we must question the extent to which alternative, new paradigms for development cooperation can really be created within this neoliberal

\section{References}

Africa Research Institute (2012) 'Between

Extremes: China and Africa', Briefing Note 1202, October, London: Africa Research Institute, www.africaresearchinstitute.org/files/briefingnotes/docs/Between-extremes-China-andAfrica-P2E56236DQ.pdf (accessed 3 December 2012)

Arnove, R.F. (1982) 'Foundations and the Transfer of Knowledge', in R.F. Arnove (ed.), Philanthropy and Cultural Imperialism, Bloomington IN: Indiana University Press Arrighi, G. (2002) 'The African Crisis: World Systemic and Regional Aspects', New Left Review 15: 5-36

Aulakh, P.S. (2006) 'Global Strategies of Brazilian Firms in an Era of Economic Liberalization', in S.C. Jain (ed.), Emerging Economies and the Transformation of International Business, Cheltenham: Edward Elgar

Bates, R.H. (1981) Markets and States in Tropical Africa: The Political Basis of Agricultural Policies, Berkeley CA: University of California Press

Bullard, N. and Bello, W. (1998) 'Taming the Tigers: The IMF and the Asian Crisis', in K.S. Jomo (ed.), Tigers in Trouble: Financial Governance, Liberalisation and Crises in East Asia, London: Zed Books

Cabral, L. and Shankland, A. (2013) Narratives of Brazil-Africa Cooperation for Agricultural Development: New Paradigms?, FAC Working Paper 051, Brighton: Future Agricultures Consortium

Gouldner, A.W. (1982) The Dialectics of Ideology and Technology: The Origins, and Future of Ideology, New York: Oxford University Press Guttal, S. (2008) 'Client and Competitor: China and International Financial Institutions', in D.-G. Guerrero and F. Manji (eds), China's New Role in Africa and the South: A Search for a New Perspective, Cape Town and Bangkok: Fahamu Books and Focus on the Global South institutional framework, as development, from whatever source, acts to facilitate capital accumulation and new forms of market socialisation. While reconfiguring relations, introducing new actors and adding new discursive frames, South-South cooperation must therefore be understood in its historical, political economic context, and in relation to the particular, diverse, and often contradictory, interests of states and capital in African agriculture.

Harvey, D. (2005) A Brief History of Neoliberalism, Oxford: Oxford University Press

Hodge, J.M. (2007) Triumph of the Expert: Agrarian Doctrines of Development and the Legacies of British Colonialism, Athens OH: Ohio University Press Lindert, K. (2006) 'Brazil: Bolsa Família Program: Scaling up Cash Transfers for the Poor', in MFDR Managing for Development Principles in Action: Sourcebook on Emerging Good Practices, 1st edn, www.mfdr.org/Sourcebook/1stEdition/ 6-1Brazil-BolsaFamilia.pdf (accessed 12 January 2013)

McCann, B. (2008) The Throes of Democracy: Brazil Since 1989, Halifax: Fenwood Publishing and London: Zed Books

McKinsey Global Institute (2010) Lions on the Move: The Progress and Potential of African Economies, Washington DC: McKinsey Global Institute, www.mckinsey.com/insights/mgi/research/ productivity_competitiveness_and_growth/ lions_on the move (accessed 3 December 2012) Papanek, G. (1969) 'Training Economists for Service in Developing Countries', in G. Bienviste and W.F. Ilchman (eds), Agents of Change: Professionals in Developing Countries, New York, Washington DC and London: Praeger Publishers

Patriota, T.C. and Pierri, F.M. (2013) 'Brazil's Cooperation for Agriculture Development and Food Security in Africa: Assessing the Technology, Finance, and Knowledge Platforms', in F. Cheru and R. Modi (eds), Agricultural Development and Food Security in Africa: The Impact of Chinese, Indian and Brazilian Investments, London: Zed Books

Perkins, J.H. (1997) Geopolitics and the Green Revolution: Wheat, Genes, and the Cold War, New York and Oxford: Oxford University Press

Roberts, M. (2009) The Great Recession: Profit Cycles, Economic Crisis. A Marxist View, Raleigh NC: Lulu Enterprises Inc.

Schneider, B.R. (2009) 'Big Business in Brazil: Leveraging Natural Endowments and State 
Support for International Expansion', in

L. Brainard and L. Martinex-Daiz (eds), Brazil as an Economic Superpower: Understanding Brazil's

Changing Role in the Global Economy, Washington DC: The Brookings Institution

Stiglitz, J. (2002) Globalization and its Discontents, London: Penguin Books

Stockwell, J. (1984) In Search of Enemies: A CIA Story, Scranton PN: W.W. Norton \& Co.

Stolte, C. (2012) 'Brazil in Africa: Just Another BRICS Country Seeking Resources?', Briefing Paper AFP/AMP BP 2012/01, London: Chatham House

Truman, H. (1949) Inaugural Address, 20 January 1949, www.bartleby.com/124/pres53.html (accessed 28 November 2012)

World Bank (1989) Sub-Saharan Africa: From Crisis to Sustainable Growth, Washington DC: World Bank
World Bank and IPEA (O Instituto de Pesquisa Econômica Aplicada/Institute of Applied Economic Research) (2011) Bridging the Atlantic. Brazil and Sub-Saharan Africa: South-South Partnering for Growth, http://siteresources.worldbank.org/AFRICAE XT/Resources/africa-brazil-bridging-final.pdf (accessed 3 April 2013)

Wu, G. and Lansdowne, H. (2008) 'International Multilateralism with Chinese Characteristics: Attitude Change, Policy Imperatives, and Regional Impacts', in G. Wu and H. Lansdowne (eds), China Turns to Multilateralism: Foreign Policy and Regional Security, London and New York: Routledge 